\title{
TULBURĂRILE DIN SPECTRUL SCHIZOFRENIEI CU DEBUT ÎN COPILĂRIE ŞI ADOLESCENŢĂ - PROVOCAREA DIAGNOSTICĂ
}

\author{
Ilinca Untu ${ }^{1}$, Ştefana Maria Moisă ${ }^{2}$, Ştefan Lucian Burlea ${ }^{3}$, Anamaria Ciubară ${ }^{1}$, \\ Vasile Valeriu Lupu², Dana-Teodora Anton-Păduraru ${ }^{2}$ \\ ${ }^{1}$ Disciplina Psihiatrie, Universitatea de Medicină şi Farmacie ,, Gr. T. Popa“, Iaşi \\ ${ }^{2}$ Disciplina Pediatrie, Universitatea de Medicină şi Farmacie ,, Gr. T. Popa “, Iaşi \\ ${ }^{3}$ Universitatea de Medicină şi Farmacie „, Gr. T. Popa “, Iaşi
}

\begin{abstract}
REZUMAT
Schizofrenia cu debut precoce şi foarte precoce, mai specific, manifestă înainte de 18, respectiv 13 ani, constituie o entitate nosologică încă insuficient explorată, ce aduce cu sine o veritabilă provocare diagnostică dată de specificitățile vârstei timpurii la care apare. Totodată, schizofrenia cu debut în copilărie şi adolescență se întrepătrunde cu o serie de tulburări ale dezvoltării neurocognitive, având şi o importantă susceptibilitate genetică. Întregul context de apariție a acesteia, dificultatea detectării simptomelor psihoproductive în copilăria mică, severitatea simptomelor şi cronicizarea, impun o conduită diagnostică riguroasă şi o abordare multidisciplinară în vederea realizării terapiei optime de lungă durată şi integrării socio-familiale a pacienților. Lucrarea de față îsi propune sintetizarea datelor din litaratura de specialitate în vederea realizării unui precursor pentru cercetări viitoare ample, care să conducă la crearea unor ghiduri de abordare specifică a schizofreniei la copil şi adolescent.
\end{abstract}

Cuvinte cheie: schizofrenie cu debut precoce, schizofrenie cu debut foarte precoce, copil şi adolescent, dezvoltare neurocognitivă, susceptibilitate genetică

\section{INTRODUCERE}

Schizofrenia este o tulburare psihiatrică severă, caracterizată prin dezorganizarea gândirii, şi prin marcate tulburări calitative persceptuale, fiind acompaniată de afecte inadecvate sau tocite, cu impact semnificativ asupra funcționalității globale a pacientului $(1,2)$.

Schizofrenia la copil si la adolescent, numită şi forma precoce de schizofrenie (cu debut mai devreme de vârsta de 18 ani), rămâne încă insuficient explorată şi cunoscută. Suprapunerea acestei entităţi nosologice pe schizofrenia adultului este extrem de relativă, existând forme clinice specifice copilăriei şi adolescenței care se impun a fi atent studiate şi cunoscute în vederea unei optime abordări diagnostice şi terapeutice $(1,2,3)$.

\section{DATE EPIDEMIOLOGICE}

Prevalența generală a schizofreniei este de aproximativ $1 \%$, însă incidența ei este mult mai semnificativă, dat fiind caracterul său cronic. $\mathrm{Cu}$ toate că schizofrenia atinge majoritar populația adultă, se estimează că aproximativ 20\% dintre pacienții cu schizofrenie îşi situează debutul simptomatic al bolii înainte de vârsta de 19 ani $(1,2)$.

Frecvența debutului schizofreniei este mai mică, cu cât vârsta este mai tânără. Astfel, $1 \%$ dintre debuturi au loc înainte de vârsta de 10 ani, 4\% înainte de 15 ani şi 43\% în cazul genului masculin şi 28\% în cazul genului feminin, înainte de 19 ani. În prezent se consideră schizofrenie cu debut precoce boala care debutează înaintea vârstei de 18 ani şi schizofrenie cu debut foarte precoce, atunci când 
debutează înaintea vârstei de 13 ani. Până în momentul de față, datele epidemiologice ce vizează schizofrenia adolescentului şi în special cea a copilului sunt foarte sărace în comparatie cu cele ce privesc aceeaşi patologie manifestată la adult. Definirea mai omogenă a subgrupelor diagnostice a favorizat obținerea unor date mai fiabile, însă în continuare prea puțin numeroase, care situează schizofrenia copilului şi adolescentului la o prevalență de $0,03 \%$ din populația generală, dintre care mai puțin de o cincime este reprezentată de schizofrenia cu debut foarte precoce. Explorarea mai amănunțită a particularităților acestor forme de schizofrenie constituie o necesitate reală, cunoaşterea la un nivel adecvat a acestei problematici facilitând crearea unor ghiduri terapeutice specifice, adaptate vârstei şi specificităților acestui grup populațional $(2,3,4)$.

\section{ELEMENTE DE ETIOLOGIE}

Schizofrenia cu debut precoce şi foarte precoce este considerată o categorie nosologică heterogenă, atât factorii genetici, cât şi cei de mediu putând contribui la debutul acesteia. Agregarea familială puternică a acesteia este deja o noțiune certificată, iar elementele psihopatologice premorbide sunt mai severe şi mai frecvente la copil/adolescent decât la adult, bazându-se pe anomalii de neurodezvoltare şi pe anomalii citogenetice $(4,5,6)$.

Majoritatea elementelor patologice de ordin neuro-cognitiv, lingvistic şi psihosocial, precum şi modificările de la nivelul structurilor cerebrale sunt similare la adultul şi copilul cu schizofrenie. Acest fapt sugerează existența unei baze comune neurobiologice pentru schizofrenia cu debut la vârsta adultă şi pentru cea cu debut în copilărie/adolescență $(4,6,7)$.

\section{PARTICULARITĂȚI ALE ASPECTULUI CLINIC ÎN SCHIZOFRENIA COPILULUI ŞI ADOLESCENTULUI}

În mod formal, schizofrenia cu debut precoce şi foarte precoce are aceleaşi criteri de diagnostic cu schizofrenia adultului. $\mathrm{Cu}$ toate acestea, se disting mai multe particularități clinico-anamnestice ale schizofreniei adolescentului, care pot fi grupate în trei categorii: forma cu functionare premorbidă în limite normale, cu o alterare treptată a structurilor psihicului, formele evolutive ale unei tulburări de spectru autist şi formele care aduc suspiciunea organicității $(2,3)$.

Nivelul de dezvoltare al copilului/adolescentului are un impact unic asupra exprimării diverselor aspecte semiologice determinate de schizofrenia $\mathrm{cu}$ debut precoce şi foarte precoce. Astfel, se remarcă dificultăți în prezentarea halucinațiilor şi/sau a ideației delirante, pusă pe baza limitării date de insuficienta dezvoltare cognitivă şi a abilităților de limbaj, care face din această formă de schizofrenie o reală provocare diagnostică $(2,6)$.

Ideația delirantă bine sistematizată şi conturată este rară în cazul copiilor cu vârste foarte fragede. Totodată, dezorganizarea gândirii şi halucinațiile apar de regulă după vârsta de 6 ani, fiind cu adevărat frecvente după 8-9 ani. În cazul copiilor preşcolari este fundamentală discernerea între ideile de natură fantastică relaționate somnului sau ce apar ca fenomen de dezvoltare, produs al imaginației şi fenomenele psihotice. De asemenea, şi halucinațiile tranzitorii pot fi întâlnite la copii în contextul unor situaţii stresante sau al unei anxietăți marcate. Aceste elemente întăresc dificultatea majoră diagnostică pe care o are schizofrenia cu debut fooarte precoce $(2,6,8)$.

Complexitatea fenomenelor psihotice creşte odată cu înaintarea în vârstă, precum şi direct proporțional cu nivelul de dezvoltare. Astfel, în adolescență, simptomatologia psihotică este similară cu cea a adultului. $\mathrm{Cu}$ toate acestea este esentială realizarea unui diagnostic diferențial corect, care să nu subestimeze posibilitatea existenței unei alte condiții psihiatrice patologice, precum tulburarea de personalitate de tip borderline, atunci când clinicianul se confruntă cu episoade psihotice de scurtă durată $(1,2,6)$.

$\mathrm{Cu}$ toate că studiile de specialitate sugerează că inteligența copiilor şi adolescenților cu schizofrenie cu debut precoce şi foarte precoce se situează sub media populației generale, $10-20 \%$ dintre aceşti pacienți având coeficientul de inteligență sub 70, numărul restrâns de indivizi analizati creează dificultăţi în extragerea unei concluzii pertinente şi bine definite (2).

\section{PROBLEMATICA DIAGNOSTICULUI DIFERENŢIAL}

Dificultatea diagnosticului pozitiv de schizofrenie la copil şi adolescent este suplimentată de necesitatea asigurării unui diagnostic diferențial riguros. Astfel, se ia în considerare posibilitatea existentei unei psihoze afective (depresie cu simptome psihotice sau tulburare bipolară), în care elementul fundamental de distincție îl constituie tocirea afectivă din schizofrenie, tulburarea schizoafectivă (insuficient cercetată la copil/adolecent), sindromul Asperger şi alte tulburări de spectru 
autist (DSM V nu exclude diagnosticul de schizofrenie în prezența unei tulburări de spectru autist, dacă fenomenele psihoproductive sunt prezente pentru cel puțin o lună), psihoza dezintegrativă a copilului, tulburări neurodegenerative, episodul psihotic pe fondul ingestiei de substanțe psihoactive şi nu în ultimul rând, epilepsia de lob temporal $(2,6,9)$.

\section{PARTICULARITĂTIILE FORMEI CU FUNCTIIONARE PREMORBIDĂ CE SUFERĂ O ALTERARE GRADUALĂ (SCHIZOFRENIA PROPRIU-ZISĂ)}

Forma cu funcționare premorbidă ce suferă o laterare treptată este forma de schizofrenie cu debut precoce care se apropie cel mai mult de aspectul schizofreniei adultului. Caracteristicile sale clinice generale nu diferă în mod fundamental de cele ale adultului, în ceea ce priveşte criteriile diagnostice stabilite conform ICD-10 şi DSM V. Deosebirile între aceste forme de schizofrenie sunt mai mult de ordin cantitativ decât calitativ. De fapt, cu toate că simptomatologia în sine este identică, studiile demonstrează că, pe măsură ce debutul este mai precoce, simptomatologia negativă este dominantă. De regulă, boala îşi situează originea înaintea evidenței sale clinice, având de cele mai multe ori un debut insidios, însotit de diverse grade de egodistonie, ce se referă la faptul că pacientul recunoaşte într-o anumită măsură anormalitatea trăirilor sale, fiind înclinat adesea să le împărtăşească adulților din anturaj. Aceştia manifestă în cele mai dese cazuri nelinişte şi destabilizare, provocând o veritabilă reticență din partea copilului/adolescentului de a mai împărtăşi simptomatologia sa adulților şi implicit medicului psihiatru, cu toate că este conştient într-o anumită măsură de caracterul patologic al acesteia, diferență majoră față de schizofrenia adultului, în care pacientul pierde total critica bolii. Aspectul aproape patognomonic al schizofreniei adultului, caracterizat prin bizarerii comportamentale şi grave dificultăţi de relaţionare se regăseşte rar în formele cu debut precoce ale bolii, în parte datorită egodistoniei. Această particularitate clinică poate conduce la erori diagnostice, adesea simptomatologia putându-se confunda cu depresia, aceasta fiind un element esențial al diagnosticului diferențial, în fața abuliei, retragerii sociale, pierderii expresivității faciale, cu toate că dispoziția tristă este rareori prezentă $(2,9,10)$.

Pe de altă parte, dincolo de simptomatologia manifestă a pacientului, s-a demonstrat că, cu cât debutul este mai precoce, cu atât se asociază mai frecvent antecedente patologice în etapele dezvoltării, instalarea insidioasă a bolii fiind net mai des întâlnită decât debuturile brutale, fără semne care să le anticipeze. Totodată este esențial şi faptul că o mare proporție a pacienților cu debut al schizofreniei la vârsta adultă prezintă antecedente de natură psihopatologică premorbidă, în copilărie $(8,9,10)$.

O serie de studii evidențiază faptul că, frecvent, în cazul schizofreniei cu debut precoce, simptomele franc psihotice sunt precedate de o alterare a limbajului, cogniţiei şi comportamentului. Adesea, aceste cazuri prezintă în antecedentele premorbide tulburări minime în neurodezvoltare, deficit prosexic şi emoţional, tulburări discrete de limbaj. Uneori, aceşti pacienți sunt marcați de tulburări de lateralizare şi de coordonare motrice $(11,12,13)$.

Schizofrenia cu debut precoce asociază o severitate crescută, având o dimensiune ereditară puternică şi o predispoziţie a sexului masculin (element comun unei mari proporții a tulburărilor psihiatrice cu debut precoce) (4).

Această formă clasică şi consensuală de schizofrenie ce afectează indivizi cu vârsta sub 18 ani se distinge printr-o simptomatologie negativă marcantă, prin prezența unor simptome premorbide mai variate şi mai numeroase decât în cazul schizofreniei adultului (2).

\section{SCHIZOFRENIA CA FORMĂ EVOLUTIVĂ A UNEI TULBURĂRI DE SPECTRU AUTIST}

Schizofrenia ca formă evolutivă a unei tulburări de spectru autist nu constituie o variantă consensuală, fiind o noțiune supusă controversei. În contextul tulburărilor grave de comunicare şi a asocierii frecvente cu întârzierea în dezvoltarea psiho-cognitivă, detectarea fenomenelor psihoproductive (halucinații şi ideaţie delirantă) este extrem de dificilă, diagnosticarea schizofreniei fiind o reală provocare. Unele studii sugerează că anumite forme de autism, precum tulburările nespecifice ale acestui spectru şi sindromul Asperger, pot evolua către schizofrenie. Astfel, autismul poate constitui un potențial factor de risc pentru schizofrenie $(2,10)$.

Din punct de vedere clinic, păstrează simptomatologia caracteristică schizofreniei, chiar dacă aspectul general este marcat de semnele neative, halucinațiile şi ideația delirantă fiind mai dificil de evidențiat $(2,3)$. 


\section{FORMELE DE SCHIZOFRENIE CU ASPECT DE ORGANICITATE}

Asocierea unei tulburări aparținând spectrului schizofreniei cu patologii organice, unele foarte rare, nu este neobişnuită. În plus, în cazul bolilor genetice, există o veritabilă intricare cu planul neurodezvoltării şi cu cel al dezvoltării psiho-afective. Aceste forme de schizofrenie au o serie de elemente atipice, care sugerează existența unei patologii organice pe fundalul simptomatologiei schizofreniforme. Caracterul atipic se evocă în fața semnelor de prim rang - halucinațiile, predominant vizuale, elementele confuzionale, elementele catatonice şi rezistența la tratamentul medicamentos clasic cu antipsihotice şi a semnelor de rang secund - debutul acut sau foarte precoce, neurodezvoltare patologică, întârziere în dezvoltarea psiho-cognitivă, antecedente familiale de psihoză $(9,13)$.

\section{COORDONATE TERAPEUTICE}

Întreaga conduită terapeutică trebuie să planeze în jurul caracterului cronic al acestei patologii, în consecinţă trebuie să asigure o continuitate în îngrijirea multidisciplinară a pacienților vizați $(9,14)$.

Din perspectiva terapiei medicamentoase, de primă intenție se folosesc antipsihoticele atipice (olanzapină, risperidonă, aripiprazol, amisulprid), majoritatea fiind aprobate pentru utilizarea la copii cu vârsta peste 13 ani. Datele din literatura de specialitate, încă foarte puțin numeroase, sugerează că frecvența efectelor adverse ale antipsihoticelor este mai crescută la această grupă de vârstă decât la adult, diskinezia, creşterea ponderală şi sedarea fiind semnificative. În faţa eşecului unei terapii cu durata de minimum 12 săptămâni, se recomandă asocierile de antipsihotice. În cazul în care nici asocierea a două antipsihotice nu aduce rezultatele scontate după alte 12 săptămâni de tratament, pacientul are o formă de schizofrenie rezistentă şi se indică luarea în calcul a inițierii tratamentului cu clozapină, cu amendamentul că impune o atentă monitorizare a hemoleucogramei în contextul riscului de agranulocitoză. Indiferent de antipsihoticul ales, sub care se continuă terapia de lungă durată, este fundamentală urmărirea atentă a potențialei apariții a efectelor adverse precum sindromul metabolic, diskinezia/distonia, sedarea excesivă (de cele mai multe ori traanzitorie) şi nu în ultimul rând, scăderea libidoului în cazul adolescenților $(14,15)$.

\section{CONCLUZII}

Schizofreniile cu debut precoce sunt forme particulare ale schizofreniei care trebuie să beneficieze de o abordare clinico-terapeutică şi ab initio, diagnostică, corectă și eficace, evaluarea genetică şi somatică fiind fundamentală în toate cazurile.

Ameliorarea prognosticului pe termen lung este fundamentală, putându-se realiza prin crearea unor siteme de suport social şi educațional pentru aceşti copii/adolescenți. Totodată, psihoterapia aplicată atât pacientului cât şi familiei acestuia, duce la o mai bună integrare a individului suferind de schizofrenie în mediul socio-familial. 